\title{
Healthcare Professional's Knowledge about Drug Related Problems in Saudi Arabia
}

\author{
Yousef Ahmed Alomi ${ }^{1 *}$, Dima Ahmad Alaskari², Malak Mohammad Almelfi², Dima Ali Badawi ${ }^{3}$, \\ Abdullah Mohammad Alshihri ${ }^{4}$ \\ ${ }^{1}$ The Past General Manager of General Administration of Pharmacentical Care and The Past Head, National Clinical pharmacy \\ and pharmacy practice and Pharmacy $R$ and D Administration, Ministry of Health, Riyadh, SAUDI ARABIA. \\ ${ }^{2}$ General Administration of Pharmaceutical Care, Ministry of Health, Riyadh, SAUDI ARABIA. \\ ${ }^{3}$ Pharmaceutical Care Services, Saudi Germany Hospital, Aseer, SAUDI ARABIA. \\ ${ }^{4}$ Head, Pharmaceutical Care Services, Abha Maternity and Children Hospital, Abha, SAUDI ARABIA.
}

Received: 02 June 2018;

Accepted: 28 August 2018

*Correspondence to:

Dr. Yousef Ahmed Alomi,

The Past General Manager of General Administration of Pharmaceutical Care, The Past Head, National Clinical pharmacy and pharmacy practice

Head, Pharmacy $R$ and $D$ Administration, Ministry of Health, P.O.BOX 100, Riyadh 11392, Riyadh, SAUDI ARABIA. Email:yalomi@gmail.com

Copyright: (c) the author(s),publisher and licensee Indian Academy of Pharmacists. This is an open-access article distributed under the terms of the Creative Commons Attribution Non-Commercial License, which permits unrestricted non-commercial use, distribution, and reproduction in any medium, provided the original work is properly cited.

\begin{abstract}
Purpose: To explore Healthcare professionals and Knowledge about Drug-related problems in Saudi Arabia. Methods: It is a 4-months cross-sectional survey of healthcare professionals and knowledge of medicines. The survey consisted of two-part, demographic information and second part forty-nine questions divided into four domains. It included domain one: Primary or essential information about healthcare providers medication, domain two: healthcare professionals information about the drug-related problem, domain three: healthcare professionals information about drug-related cost and domain four: Healthcare providers perception of medications. Medline Plus health information and Daily Med-INH elements information from National Institute of Health United State of America were used. The survey distributed through social media by using what's App to more than one thousand healthcare professionals overall Kingdom of Saudi Arabia. The survey was made in an electronic format, and it analyzed domain two : healthcare professional's information about the drug-related problem through survey monkey system. Results: The total responders were (188) Healthcare professionals. Of those 177 (95.16\%) were Saudi and 9 (4.84\%) were non-Saudi. The gender distribution 120 (63.83\%) were females and 68 (36.17\%) were males. The most of Healthcare professionals were pharmacist 93 (71.54\%), followed by nurses $18(13.85 \%)$ and physicians $15(11.54 \%)$. The most type of medications used was anti-hypertension medicines, anti-diabetic medicines, Skin medications and drugs for Respiratory Diseases. The healthcare professionals showed good knowledge either complete or incomplete information about the adverse drug reaction either a general side effect of medications 135 (74.2\%) or potential adverse event about their medications 128 (69.9\%). More than half of responders were familiar with drug overdose behaving 112 (60.86\%) or first aid of drug poisoning 112 $(61.87 \%)$. The responder showed not adequate awareness of contraindication of medicines used with other diseases condition 117 (63.24\%), drugs 113 (61.74\%), food 119 (64\%) or laboratory test 120 (64.51\%) and $103(56.6 \%)$ with the herbal drug. The responders showed adequate knowledge either complete or incomplete information about the use of medications for children 131 (71.2\%) or elderly $128(69.56 \%)$, drug use during pregnancy $132(72.1 \%)$ or breastfeed $128(69.56 \%)$. Conclusion: One-third of healthcare professionals were not familiar with essential drug-related problems information. It is critical toward drug misadventures and cost burden in the society. Very comprehensive and urgent implementation of the healthcare professional's education program about medications required in Saudi Arabia.
\end{abstract}

Key word: Healthcare professional, Knowledge, Drug-related problems, Ministry of Health, Saudi Arabia.

\section{INTRODUCTION}

The drug-related problems are a very critical element in the management of the acute or chronic diseases. The drug misadventures are potential and may lead to an emergency visit or hospital admission. ${ }^{[1-3]}$ Also, may implicate critical care admission or permanent disability or death with the high economic burden on the healthcare system. The healthcare professionals included all type of physicians, pharmacists or nurses and had significant role in preventing the drug-related problems. To prevent drug misuse, it needs a first medication-related problems knowledge and background. A healthcare provider can improve the use of medicines or can increase their maladies and problems. The main reason is to provide the drug users with all the necessary information they need to prevent Drug-related problems and reduce them as much as possible that this is one of the most significant problems that may concern the use of medications. Adverse drug reactions are global problems of significant concern. ${ }^{[4]}$ Patients with not adequate or wrong information regarding the medication can lead to the incorrect use of medications that caused a reduction in its efficacy or other health problems. They should also, make the patient more aware of how to use the 
medication, dosages and side effects. That may result from the medication used and the proper way to deal with it. Because Patients with negative attitudes towards their illness can be unwilling to follow the advice in their management plans. The usage of Patient's knowledge of medication is not in the prevention of drug-related problems; but also a sign to influence the treatment success with an opportunity for one to attain a full health potential. ${ }^{[5]}$ The increasing dependence on medication therapy as the primary intervention for most diseases. The patients receiving medications are more susceptible than ever to potential harm adverse drug events (ADEs) and medication errors. Few investigations disused Healthcare care professionals and medication knowledge including drug-related problems. ${ }^{[6-7]}$ Most of the studies discussed each specialty alone or combined with all drug knowledge elements. Moreover, it hard to find local or Gulf and Middle East counties trail about healthcare professional's knowledge on drug-related problems. The objective of the study to explore knowledge background of healthcare professionals in Kingdom of Saudi Arabia.

\section{METHODS}

It is a 4-months cross-sectional survey of healthcare professionals and knowledge of medicines. The survey consisted of two-part, demographic information and second part included forty-nine questions divided into four domains. It included domain one: Primary or essential information about healthcare providers medication, domain two: healthcare professionals information about the drug-related problem, domain three: healthcare professionals information about drug-related cost and domain four: Healthcare providers perception of medications. All type of healthcare professionals included in the study. Medline Plus health information and DailyMed-INH elements information from National Institute of Health United State of America were used. ${ }^{[2-3]}$ The 5-point Likert response scale system used. The questions were open and closed-ended. The survey distributed through social media by using what's App to more than one thousand healthcare professionals overall Kingdom of Saudi Arabia. A message reminder was sent to healthcare professionals after two weeks and additional message reminder was sent to healthcare professional after four weeks. The survey was made in an electronic format and it analyzed domain two healthcare professional's information about the drug-related problem through survey monkey system.

\section{RESULTS}

The total responders were (188) Healthcare professionals. Of those 177 $(95.16 \%)$ were Saudi and $9(4.84 \%)$ were non-Saudi. The gender distribution $120(63.83 \%)$ were females and $68(36.17 \%)$ were males. The majority of them in age (18-44) $86.7 \%$ and located at Asir region 89 (47.34\%) and Riyadh region $46(24.5 \%)$. The most of Healthcare professionals were pharmacists $93(71.54 \%)$, followed by nurses $18(13.85 \%)$ and physicians $15(11.54 \%)$. The most responders qualification was the Bachelor Degree $126(67.02 \%)$ followed by Diploma 33 (17.55\%) and Master degree $22(11.70 \%)$ The most type of medications used was anti-hypertension medicines, anti-diabetic medicines, Skin medications and drugs for Respiratory Diseases. Also, the most number of medication taken either one $29(15.85 \%)$ or two 17 $(9.29 \%)$ as explored by Table 1 . The healthcare professionals showed good knowledge either complete or incomplete information about the adverse drug reaction either a general side effect of medications $135(74.2 \%)$ or potential adverse event about their medications 128 (69.9\%). More than half of responders were familiar with drug overdose behaving $112(60.86 \%)$ or first aid of drug poisoning $112(61.87 \%)$ as explored in Table 2. The responder showed not adequate awareness of contraindication of medicines used with other diseases condition 117 (63.24\%), drugs $113(61.74 \%)$, food $119(64 \%)$ or laboratory test $120(64.51 \%)$ and $103(56.6 \%)$ with the herbal drug as explored in Table 3. The responders showed adequate knowledge either complete or incomplete information about the usage of medications

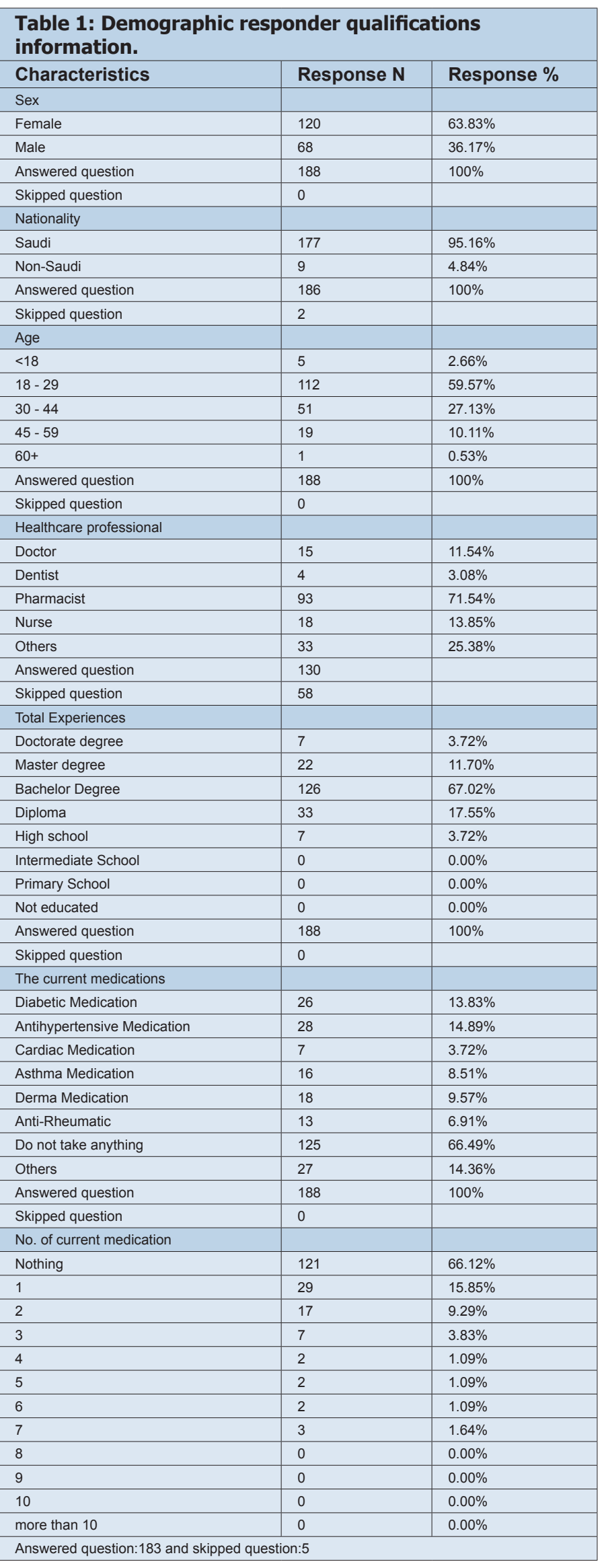


Alomi, et al:: Study about Drug Information Issues among Healthcare Professionals

Table 2: Adverse drug reaction information of medications used

\begin{tabular}{|c|c|c|c|c|c|c|c|c|}
\hline No. & Answer Options & $\begin{array}{l}\text { Complete } \\
\text { information }\end{array}$ & $\begin{array}{l}\text { Incomplete } \\
\text { information }\end{array}$ & $\begin{array}{l}\text { Weak } \\
\text { information }\end{array}$ & $\begin{array}{l}\text { do not have } \\
\text { this information }\end{array}$ & $\begin{array}{l}\text { Does not } \\
\text { need this } \\
\text { information }\end{array}$ & $\begin{array}{l}\text { Rating } \\
\text { Average }\end{array}$ & $\begin{array}{l}\text { Response } \\
\text { Count }\end{array}$ \\
\hline 1 & The adverse drug reaction information & 90 & 45 & 20 & 13 & 14 & 4.01 & 182 \\
\hline 2 & $\begin{array}{l}\text { The potential or dangerous adverse } \\
\text { drug reaction }\end{array}$ & 79 & 49 & 21 & 18 & 16 & 3.86 & 183 \\
\hline \multicolumn{9}{|c|}{ Answered question:184 and skipped question 4} \\
\hline \multicolumn{9}{|c|}{ The overdose or poisoning management information of medications used } \\
\hline & Answer Options & $\begin{array}{l}\text { Complete } \\
\text { information }\end{array}$ & $\begin{array}{l}\text { Incomplete } \\
\text { information }\end{array}$ & $\begin{array}{l}\text { Weak } \\
\text { information }\end{array}$ & $\begin{array}{l}\text { do not have } \\
\text { this information }\end{array}$ & $\begin{array}{l}\text { Does not } \\
\text { need this } \\
\text { information }\end{array}$ & $\begin{array}{l}\text { Rating } \\
\text { Average }\end{array}$ & $\begin{array}{l}\text { Response } \\
\text { Count }\end{array}$ \\
\hline 1 & $\begin{array}{l}\text { The information of facing of drug } \\
\text { overdose or poisoning }\end{array}$ & 52 & 60 & 24 & 35 & 13 & 3.56 & 184 \\
\hline 2 & The first aid when poisoning occurs & 52 & 60 & 27 & 30 & 12 & 3.61 & 181 \\
\hline
\end{tabular}

\begin{tabular}{|c|c|c|c|c|c|c|c|c|}
\hline No. & Answer Options & $\begin{array}{l}\text { Complete } \\
\text { information }\end{array}$ & $\begin{array}{l}\text { Incomplete } \\
\text { information }\end{array}$ & $\begin{array}{l}\text { Weak } \\
\text { information }\end{array}$ & $\begin{array}{l}\text { do not } \\
\text { have this } \\
\text { information }\end{array}$ & $\begin{array}{l}\text { does not } \\
\text { need this } \\
\text { information }\end{array}$ & $\begin{array}{l}\text { Rating } \\
\text { Average }\end{array}$ & Response N \\
\hline 1 & $\begin{array}{l}\text { The usage of medications } \\
\text { with diseases are forbidden }\end{array}$ & 70 & 47 & 25 & 20 & 23 & 3.65 & 185 \\
\hline 2 & $\begin{array}{l}\text { The use of medication with } \\
\text { other drugs are forbidden }\end{array}$ & 69 & 44 & 29 & 24 & 17 & 3.68 & 183 \\
\hline 3 & $\begin{array}{l}\text { The use of medicines with } \\
\text { certain foods are forbidden }\end{array}$ & 64 & 55 & 21 & 27 & 19 & 3.63 & 186 \\
\hline 4 & $\begin{array}{l}\text { The use of medicines with } \\
\text { Laboratory tests are forbidden }\end{array}$ & 62 & 58 & 19 & 27 & 20 & 3.62 & 186 \\
\hline 5 & $\begin{array}{l}\text { The use of medicines with } \\
\text { herbs are forbidden }\end{array}$ & 47 & 56 & 25 & 35 & 19 & 3.42 & 182 \\
\hline
\end{tabular}

\section{Table 4: The medication information used in a particular situation}

\begin{tabular}{|c|c|c|c|c|c|c|c|c|}
\hline No. & Answer Options & $\begin{array}{l}\text { Complete } \\
\text { information }\end{array}$ & $\begin{array}{l}\text { Incomplete } \\
\text { information }\end{array}$ & $\begin{array}{l}\text { Weak } \\
\text { information }\end{array}$ & $\begin{array}{l}\text { do not } \\
\text { have this } \\
\text { information }\end{array}$ & $\begin{array}{l}\text { does not } \\
\text { need this } \\
\text { information }\end{array}$ & $\begin{array}{l}\text { Rating } \\
\text { Average }\end{array}$ & $\begin{array}{l}\text { Response } \\
\mathbf{N}\end{array}$ \\
\hline 1 & The medication used for children & 78 & 53 & 24 & 8 & 21 & 3.86 & 184 \\
\hline 2 & The medication used for elderly & 66 & 62 & 26 & 10 & 20 & 3.78 & 184 \\
\hline 3 & The medication used for pregnancy & 84 & 48 & 15 & 12 & 24 & 3.85 & 183 \\
\hline 4 & The medication used for breast feeding & 75 & 53 & 16 & 14 & 26 & 3.74 & 184 \\
\hline 5 & The medication used for sport & 55 & 57 & 25 & 26 & 20 & 3.55 & 183 \\
\hline 6 & The medication used for practicing job & 71 & 48 & 25 & 19 & 21 & 3.70 & 184 \\
\hline
\end{tabular}

for children $131(71.2 \%)$ or elderly $128(69.56 \%)$, drug use during pregnancy $132(72.1 \%)$ or breastfeeding $128(69.56 \%)$. In addition to during exercises $112(61.2 \%)$ or practicing the job $119(64.67 \%)$ as explored in Table 4.

\section{DISCUSSION}

The General Administration of Pharmaceutical Care in Ministry of Health founded the updated pharmacy strategic plan to prevent drug misadventures and prevent harm to the patients. ${ }^{[8]}$ Several programs are involved in this area for instant medication safety program, medication reconciliation services, follow up and documents drug quality reporting system. ${ }^{[9-10]}$ Also, the new edition of Saudi Center for Organization Accreditation standards release the mandatory Essential Requirements Standards (ESR) to implement at all hospitals to prevent any mistakes or drug-related problems to reach the patients. Not taking own medicines as a prescribed lead to less therapeutic outcomes or under or overdoe-related problems. It can result in additional medication intake, with unnecessary investigations or hospitalization. ${ }^{[1]}$ All those foundation elements need to improve the drug-related problems information and knowledge background of healthcare professionals. The investigator tried to explore the actual healthcare provider's knowledge of drug-related problems. The findings showed that only two third of The healthcare professionals showed good knowledge about the adverse drug 
reaction related issues while half of them had knowledge of medications contraindications with disease or drugs or food and laboratory test or herbal medication. It was concluded that there was not appropriate background information with healthcare professionals and may be implicated with patients management and not monitored to well treating of drug-related problems occurs with the patient then raise the economic burden on health care system. The results resemble what reported by Jodlowski, TZ et al. with knowledge of pharmacists about drug related problems. ${ }^{[12]}$ The others finding of drug-related knowledge including use of medications with pediatric or geriatrics or during pregnancy and breastfeeding had adequate knowledge due to a high-risk population and any mistake will harm the patient and healthcare knew necessary to avoid that has occurred. The results were better than what reported by Jodlowski, TZ et al. with knowledge of pharmacists about drug during pregnancy, ${ }^{[12]}$ because most patients were no taking Antiretroviral medications. The finding of medications knowledge during sport or unique jobs showed not adequate level because most of our patient does not practice exercises during lifestyles and health information with the job not existed at most of the times, also, most of governmental or privates job they do not practice healthcare information at their situations. It could not compare with other studies due to most of the investigations not mentioned all the findings. Moreover, this considered as a serious and that indicates the misuse of medicines, resulting in a substantial burden on the cost and negatively affects society. Given the constraints on consultation times within general practice, it may be reasonable to consider alternative information sources as more suited to providing the depth and detail of information required, ${ }^{[13]}$ that may reduce the Drug-related problems. The pharmacists should often verify patient understanding verbally, these methods may typically provide evidence about what patients learn. ${ }^{[14]}$ It may be helpful in reducing drug-related problems. So, it needs a comprehensive and very urgent program of vocational education in the field of healthcare about the required medicines in Saudi Arabia.

\section{CONCLUSION}

Healthcare professional including physicians, pharmacists and nurses had a deficiency of medication knowledge of drug-related problems. Targeting of education and training of healthcare providers with emphasis on knowledge about drug-related problems is highly recommended at all governmental and private healthcare organizations in Kingdom of Saudi Arabia.

\section{ACKNOWLEDGMENT}

None

\section{CONFLICT OF INTEREST}

None

\section{ABBREVIATION}

KSA: Kingdom of Saudi Arabia; MOH: Ministry of Health; CBAHI: Saudi Center for Accreditation of Healthcare Institutions.

\section{REFERENCES}

1. Al-Olah $\mathrm{YH}, \mathrm{Al}$ Thiab KM. Admissions through the Emergency Department due to Drug-Related Problems. Ann Saudi Med. 2008;28(6):426-9.

2. Al-Arifi M, Abu-Hashem H, Al-Meziny M, Said R, Aljadhey H. Emergency department visits and admissions due to drug-related problems at Riyadh military hospital (RMH), Saudi Arabia. Saudi Pharm J. 2014;22(1):17-25.

3. Alghamdy MS, Randhawa MA, Al-Wahhas MH, Al-Jumaan MA. Admissions for drug-related problems at the Emergency Department of a University Hospital in the Kingdom of Saudi Arabia. J Family Community Med. 2015;22(1):44-8.

4. Gurmesa LT, Dedefo MG. Factors affecting adverse drug reaction reporting of healthcare professionals and their knowledge, attitude and practice towards ADR reporting in Nekemte Town, West Ethiopia. Biomed Res Int. 2016;2016:5-8.

5. Ssemaluulu R, Adome R. Patients' knowledge of medication use as an equity issue in health care : Do health workers pay attention to this?. 2006. Available from: http://www.equinetafrica.org/sites/default/files/uploads/documents/ CBP3EHSadome.pdf

6. West CP, Shanafelt TD, Kolars JC. Quality of Life, Burnout, Educational Debt and Medical Knowledge Among Internal Medicine Residents. JAMA. 2011;306(9).

7. Salhia HO, Ali A, Rezk NL, El Metwally A. Perception and attitude of physicians toward local generic medicines in Saudi Arabia: A questionnaire-based study. Saudi Pharm J. 2015;23(4):397-404.

8. Alomi YA, Alghamdi SJ, Alattyh RA. Strategic Plan of General Administration of Pharmaceutical Care at Ministry of Health in Saudi Arabia 2012-2022. J Pharm Pharm Sci. 2015;1(3):1-8.

9. Alomi YA. National Medication Safety Program at Ministry of Health in Saudi Arabia. J Pharmacovigi. 2015;3(5):1-2.

10. Alomi YA, Kamal E, Alomi, Kamal, Pharmacovigilance. National Drug Quality Reporting System at Ministry of Health in Saudi Arabia. J Pharmacovigil. 2016;4(208):2.

11. Patel MJ, Shetty L, Rasras A. Assessment of Medication Adherence and Medication Knowledge among Hypertensive Patients in Riyadh, Saudi Arabia. Int J Pharma Res Rev. 2015;4(10):15-23.

12. Jodlowski TZ, Sym D, Conry J, Kanmaz T. Antiretroviral medication knowledge among New York State pharmacists: room for improvement. J Pharm Pract. 2010;23(5):507-10.

13. Williams L, Caskey H, Coates V, Thompson K, Helen S. A survey of patients' knowledge of their diabetes medication. J Diabetes Nurs. 2007;11(7):264-9.

14. Briggs AL, Jackson TR, Bruce S, Shapiro NL. The development and performance validation of a tool to assess patient anticoagulation knowledge\{star, open\}. Res Soc Adm Pharm. 2005;1(1):40-59.

Cite this article as: Alomi YA, Alaskari DA, Almelfi MM, Badawi DA, Alshihri AM. Healthcare Professional's Knowledge about Drug Related Problems in Saudi Arabia. J Pharm Pract Community Med. 2018;4(3):159-62. 